\title{
Biometric characteristics among fig tree genotypes in Brazil
}

\author{
M.G.F. Rodrigues ${ }^{1,}$ L.N.H. Monteiro ${ }^{2}$, A.F.A. Ferreira ${ }^{3}$, T.P. Dos Santos ${ }^{1}$, \\ B.E. Pavan ${ }^{4}$, V.A.B. Neves ${ }^{1}$ and A.C. Boliani ${ }^{4}$ \\ ${ }^{1}$ Faculdade de Ciências Agrárias e Tecnológicas, Departamento de \\ Engenharia Agronômica, Dracena, SP, Brasil \\ ${ }^{2}$ Faculdade de Ciências Agrárias, Departamento de Horticultura, Botucatu, \\ SP, Brasil \\ ${ }^{3}$ Universidade do Estado do Mato Grosso, Alta Floresta, MT, Brasil \\ ${ }^{4}$ Faculdade de Engenharia de Ilha Solteira, Departmento de Fitotecnia, \\ Engenharia Rural e Sócio-economia, Ilha Solteira, SP, Brasil
}

Corresponding author: M.G.F. Rodrigues

E-mail: mariagabriela@dracena.unesp.br

Genet. Mol. Res. 18 (2): gmr18191

Received October 28, 2018

Accepted March 29, 2019

Published April 30, 2019

DOI http://dx.doi.org/10.4238/gmr18191

\begin{abstract}
Fig (Ficus carica) is among the 20 main fruits exported by Brazil, which is the eighth largest producer of fresh figs. The characterization of active fig germplasm banks has thus become an important line of research, as it is necessary to gather information to carry out adequate management projects. The objective of this study was to characterize the morphologies of 42 fig tree accessions belonging to the Faculty of Engineering of Ilha Solteira of the University of Sao Paulo State, so that the quality and genetic potential of different accessions of the species could be recognized based on the characteristics of the vegetative parts of the plants. Estimates of variance components were obtained for each variable evaluated using the restricted maximum likelihood/best linear unbiased prediction procedure, available in the genetic-statistical software SELEGEN. Most of the morphological characteristics of fig accessions examined had heritability values ranging from 0.25 to 0.40 . However, the number of leaf lobes showed high heritability (0.85), with a genotypic and environmental coefficients of variation ratio higher than 1 . This population has medium to high genetic variability; allowing us to identify the materials based on morphological descriptors, among which the number of lobes of the leaves appeared to be the most promising.
\end{abstract}


Key words: Ficus carica; Conservation of genetic resources; Phenotypic characterization; Active germplasm bank; Fig plant breeding

\section{INTRODUCTION}

The common fig tree, Ficus carica, is a fruit tree belonging to the family Moraceae, which is able to adapt to a wide diversity of climates. It is cultivated both in warm subtropical regions and in temperate climates (Flaishman et al., 2008). According to Barolo et al. (2014), in addition to its use as an important source of vitamins and minerals in the supplementation of human diets, the fig plant has been used to improve poor health conditions, since its fruits, leaves, and latex have been reported to act as antioxidants in diabetic mice (Pérez et al., 2003), inhibitors of low-density lipoprotein (LDL) oxidation in humans (Mawa et al., 2013), and inhibitors of cancer cell proliferation (Rubnov et al., 2001).

In addition to these interesting features of the fig, fig production is characterized as an activity carried out in rural areas, which contributes to the survival of family farms and acts as a source of income for small and medium producers. Therefore it is of great importance to the social balance of the rural population, generating more jobs in the field because it requires labor throughout the year.

However, the commercial cultivation of the fig tree in Brazil is exclusively based on the planting of a single cultivar, 'Roxo-de-Valinhos', which is characterized by its high vigor, productivity, hardiness, and wide acceptance by consumers and the industry (Ferreira et al., 2009).

This predominance of a single cultivar results in serious pest and disease problems, such as fig rust (Cerotelium fici), fig tree borer (Azochis gripusalis), and fig fly (Zaprionus indianus), which hinder cultivation and depreciate fruits, reducing profits. This practice also makes fig trees very susceptible to the nematode Meloidogyne incognita, which attacks the roots of the plant and forms galls, harming its development and requiring high expenditures for crop inputs and cultural treatments for this pest (Brito et al., 2008).

Thus, research aiming at finding solutions to some of these problems would make an enormous contribution to the development of fig cultivation, such as allowing the use of resistant cultivars as a viable strategy. Considering that genetic diversity is an important component of the survival of a species and its adaptation to changes in the environment, the characterization and maintenance of such diversity in existing active germplasm banks (AGBs) becomes a fundamental strategy for the improvement of the culture of species like fig (He et al., 2016).

Within this context, the objective our present study was to perform a morphological characterization of accessions in the AGB of Fig ( $F$. carica) belonging to the Faculty of Engineering of Ilha Solteira (FEIS) of UNESP through quantitative descriptors. This was done to support future studies on the conservation and genetic improvement of this species.

\section{MATERIAL AND METHODS}

This study was carried out using 42 fig tree accessions 15 years old, belonging to the Active Germplasm Bank (AGB) of Fig at the Teaching, Research, and Extension Farm of the Faculty of Engineering of Ilha Solteira (FEIS) of University of São Paulo State 
(UNESP) - Ilha Solteira Campus, located in the municipality of Selvíria, MS, Brazil (latitude $20^{\circ} 22^{\prime} \mathrm{S}$, longitude $51^{\circ} 2^{\prime} \mathrm{W}$, altitude approximately $335 \mathrm{~m}$ ).

The climate of the region is 'Aw' (i.e. Tropical savanna climate or tropical wet and dry climate) according to the classification of Koeppen (1948), with an average annual temperature of $24.5^{\circ} \mathrm{C}$ (average maximum of $27.5^{\circ} \mathrm{C}$ and minimum of $21.4^{\circ} \mathrm{C}$ ), relative air humidity of around $64.8 \%$ (annual average), and a pluviometric index of $1232 \mathrm{~mm}$ (average) distributed from October to March. The soil is classified as dystrophic Red Latosol, a moderate, very clayey, hypodystrophic, kaolinitic, ferric, epicompact, very deep, and moderately acid soil, according to the Brazilian Soil Classification System. Production fertilizations were performed according to soil analysis results and recommendations of Raij et al. (1997), in the projection of the crown of the fig trees, with the soil devoid of mulch. Phytosanitary treatment was carried out with bi-weekly applications of Bordeaux mixture $(1 \%)$ intercalated with mancozeb $(200 \mathrm{~g}$ p.c./100 L of water) to control fig rust (Cerotelium fici Cast.), and Methyl Parathion (100 mL/100 L of water) to control fig borer (Azochis gripusalis Walk.), applied alternately.

To protect the soil against erosion, maintain soil moisture, and control weeds, mulch was used in the inter-row spaces after pruning. Irrigation was done using a drop tube system 3 times a week, with an average precipitation of $2.0 \mathrm{~mm} / \mathrm{h}$ reaching an area of 50 $\mathrm{cm}$ width in the planting row. This was considered to result in an average coefficient of class A tank $(\mathrm{Kp})$ of 0.75 and a crop coefficient $(\mathrm{Kc})$ for fig trees equal to 1 .

The number of lobes per leaf in the first fruit of the single stem of each plant was counted. Length and width of the leaf blade $(\mathrm{cm})$ and petiole length of the leaves $(\mathrm{cm})$ were also measured with the aid of a graduated ruler. Statistical analyses were carried out on the biometric results from all accessions in each evaluation period. The averages obtained were compared using Scott Knott test at a 5\% probability significance threshold. The software Statistical Analysis and SISVAR, version 4.0 (Ferreira, 2011) were used to perform statistical analyses and experimental planning, respectively.

Estimates of the variance components were obtained for each variable using the restricted maximum likelihood/best linear unbiased prediction (REML/BLUP) procedure available in the genetic-statistical software SELEGEN - Computerized Genetic Selection developed by Resende, (2007). The statistical model used was:

$$
\mathrm{y}=\mathrm{Xr}+\mathrm{Zg}+\mathrm{e}
$$

where: $y$ is the data vector; $r$ is the vector of the repetition effects (fixed) added to the general average; $g$ is the vector of genotypic effects (random) and "e" is the vector of (random) errors.

The capital letters represent the matrices of evidence for these effects (Resende, 2007). The components of variance and descriptive statistics calculated were genetic variance, residual variance, heritability $\left(\mathrm{h}^{2}\right)$, genotypic $(\mathrm{CVg})$ and environmental coefficients of variation ( $\mathrm{CVe}$ ), overall average of the experiment for all variables, and the $\mathrm{CVg} / \mathrm{CVe}$ ratio.

To assess the genetic divergence among the accessions in terms of the biometric characters of their roots and leaves, the generalized Mahalanobis distance was used (Matos, Munõs and Gonzáles, 2013). The genotypes of different accessions were separated from one another using the software GENES (Cruz et al., 2006) to generate the dendrogram. The characters examined, the accessions, and their places of origin are presented in Table 1. 
Table 1. Identification of the 42 fig tree (Ficus carica) accessions used for morphological and agronomic descriptions of leaves and fruits in this study, belonging to the Faculty of Engineering of Ilha Solteira (FEIS) of UNESP, in 2017.

\begin{tabular}{|c|c|c|}
\hline TREATMENTS & ACCESSIONS & ORIGIN \\
\hline 1 & Calimyrna & São José do Rio Preto \\
\hline 2 & Nobile & IAC \\
\hline 3 & 'Genovesco' & IAC \\
\hline 4 & 'Roxo-de-Valinhos' & São Sebastião do Paraíso \\
\hline 5 & Stanford & IAC \\
\hline 6 & White Adriatic & IAC \\
\hline 7 & 'Celeste' & IAC \\
\hline 8 & 'Bonato' & IAC \\
\hline 9 & White Genova & São José do Rio Preto \\
\hline 10 & White Genova & IAC \\
\hline 11 & Smyrna & IAC \\
\hline 12 & Smyrna & São José do Rio Preto \\
\hline 13 & Brunswich & IAC \\
\hline 14 & 'Caprifigo' & IAC \\
\hline 15 & 'Troyano' & IAC \\
\hline 16 & Brown Turkey & Ilha Solteira \\
\hline 17 & 'Pingo de Mel' & IAC \\
\hline 18 & 'Palestino' & Campinas \\
\hline 19 & 'Turco' & Campinas \\
\hline 20 & 'Figo Rojo' & Piracicaba \\
\hline 21 & IP 21 & Ilha Solteira \\
\hline 22 & Accession 26 & Monte Alto \\
\hline 23 & Accession 27 & Monte Alto \\
\hline 24 & Accession 28 & Monte Alto \\
\hline 25 & Accession 29 & Monte Alto \\
\hline 26 & Accession 30 & Monte Alto \\
\hline 27 & Accession 31 & Monte Alto \\
\hline 28 & Accession 32 & Monte Alto \\
\hline 29 & Accession 33 & Monte Alto \\
\hline 30 & Accession 34 & Monte Alto \\
\hline 31 & Accession 35 & Monte Alto \\
\hline 32 & Accession 36 & Monte Alto \\
\hline 33 & Accession 37 & Monte Alto \\
\hline 34 & Accession 38 & Monte Alto \\
\hline 35 & Accession 39 & Monte Alto \\
\hline 36 & Accession 41 & Monte Alto \\
\hline 37 & Accession 42 & Monte Alto \\
\hline 38 & Accession 44 & Monte Alto \\
\hline 39 & Accession 45 & Monte Alto \\
\hline 40 & 'Mini Figo' & IAC \\
\hline 41 & 'Caprifigo' & Ilha Solteira \\
\hline 42 & 'Figo Negro' & Piracicaba \\
\hline
\end{tabular}

IAC: Agronomic Institute of Campinas; IP: Irradiated Plant.

\section{RESULTS AND DISCUSSION}

The characterization and evaluation of plant species consists of establishing an identity for each accession, through the knowledge of a series of data aiming to describe the different accessions of a collection of germplasm, using characteristics of interest. Cruz et al. (2014) mentioned that the characters studied may be morphological, physiological, cytological, biochemical, or molecular, and should include attributes, characteristics, or 
traits of a culture that are informative and useful for the characterization and evaluation of specific types (i.e. accessions) of the studied species.

Most of the morphological characteristics of fig leaf accessions examined in this study presented a genotypic coefficient of variation lower than the environmental coefficient of variation and had heritability values ranging from 0.25 to 0.40 . However, traits in all accessions were found to have non-zero heritability, showing that there is genetic variability among the accessions in the characters tested. Estimates of genetic parameters for these characteristics are presented in Table 2.

Table 2. Variance components and genetic parameters for leaf length, leaf width, number of lobes, and length of petiole of adult fig tree accessions.

\begin{tabular}{lcccc}
\hline CV and Genetic & \multicolumn{4}{c}{ CHARACTERS } \\
\cline { 2 - 5 } Parameters & Length & Width & Lobes & Petiole \\
\hline$\delta \mathrm{g}^{2}$ & 3.058 & 2.577 & 1.309 & 1.323 \\
$\delta \mathrm{e}^{2}$ & 3.643 & 5.548 & 0.152 & 1.649 \\
$\delta \mathrm{f}^{2}$ & 7.563 & 10.209 & 1.539 & 4.085 \\
$\mathrm{hg}^{2}$ & 0.40 & 0.25 & 0.850 & 0.32 \\
$\mathrm{CVg}(\%)$ & 14.310 & 14.510 & 5.6 & 17.92 \\
$\mathrm{CVe}(\%)$ & 13.34 & 11.06 & 20.43 & 20.06 \\
$\mathrm{GA}$ & 12.22 & 16.23 & 6.96 & 0.89 \\
$\mathrm{CVg} / \mathrm{CVe}$ & 0.91 & 0.68 & 2.93 & \\
\hline \multicolumn{2}{c}{$\sigma_{g}^{2}:$ genotypic variance; $\sigma_{e}^{2}:$ variance of the experimental error; $\sigma_{f}^{2}:$ phenotypic variance; $h_{g}^{2}:$}
\end{tabular}

heritability; $C V_{g i} \%$ : genetic coefficient of variation; $C V_{e} \%$ : environmental coefficient of variation; GA: general average of all genetic parameters.

Although the findings of Cowart and Graham (1999) indicated that the length and width of the leaves are not good biometric characteristics, it is worth noting that higher values of these traits in combination with other characteristics can help in determining possible selection characters. Castellen et al. (2007), characterizing 68 accessions of the Active Germplasm Bank of Papaya of Embrapa Mandioca and Tropical Fruit through multivariate analysis, detected that the components 1 (petiole color) and 2 (leaf length) explained most of the total observed genetic variation $(67.80 \%)$.

In this sense, despite the low heritability observed for these characters in the Germplasm Bank in question, accession 15 ('Troyano') stands out from the other accessions due to its above-average leaf area, with leaf length and width of $30.3 \mathrm{~cm} 25$ $\mathrm{cm}$, respectively.

The number of leaf lobes showed high heritability (0.85), with a $\mathrm{CVg} / \mathrm{Cve}$ ratio higher than 1. In a study by Domiciano et al. (2015) on genetic parameters and diversity in progenies of macaúba (Acrocomia aculeata), estimates of heritability varied between 50.24 and $71.9 \%$ (height and length of the rachis, respectively). According to that study, these values were considered high, especially when analyzed together with those obtained for the coefficients of genetic $(\mathrm{CVg})$ and environmental variation $(\mathrm{CVa})$ 
$(\mathrm{CVg} / \mathrm{CVa}$ in most cases approached 0.5). In this study, the same authors concluded that it is possible to improve the recognition of morphological characteristics of a species through the selection of promising genotypes.

For the number of leaf lobes character, the values observed ranged from three non-pronounced to seven well-defined lobes; these extremes were observed in accessions 15 ('Troyano') and 13 ('Brunswich'), respectively (Figure 1). According to Giraldo et al. (2015), who analyzed fig varieties, the selection of highly discriminant descriptors is important to optimize the resources necessary for a viable and reliable morphological characterization. This is especially important in cultures that have accessions stored in germplasm banks with high numbers of homonyms and synonymy, as is in the present study. In this case, a rapid characterization of the germplasm with this list of descriptors would reduce the number of redundant accessions, which would allow human and financial resources to be invested more efficiently into the accurate evaluation of quantitative descriptors in different years and places of cultivation.

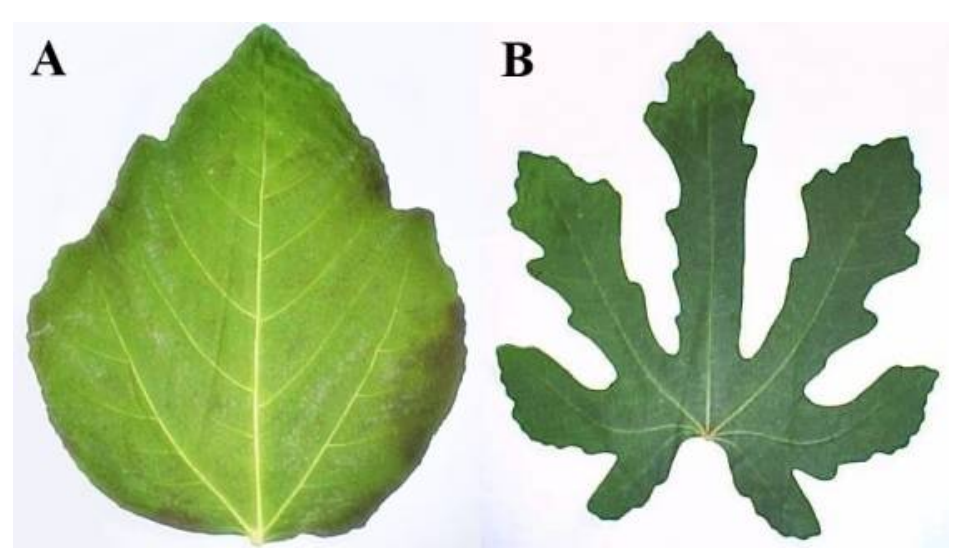

Figure 1. Fig leaves, (A) cultivar 'Troyano', referring to accession 15 and (B) cultivar 'Brunswich', referring to accession 13 of the Active Fig Germplasm Bank, at the Faculty of Engineering of Ilha Solteira (FEIS), UNESP, with three small lobes, 2017.

An adequate descriptor should allow the distinction between different accessions from the same culture to be feasible and also should be useful, avoid redundancy, be environmentally stable, and be easily manipulated by the breeder (Grum and Atieno, 2007). For example, biometric data, which have an important ecological value in helping to determine the variability within a species, allow researchers to identify and differentiate phenotypic parameters among the individuals of a population, which constitutes one of the most important sources of variability available for crop improvement (Röper et al., 2015; Palace et al., 2016; Stojanović et al., 2016).

Further analyses to infer the structure of genetic distances among the fig tree accessions in terms of leaf phenotypic characters were obtained by using Generalized Mahalanobis Distance methods, with a dissimilarity matrix and clustering determined by Ward's hierarchical grouping method. The grouping of these accessions is represented by the dendrogram in Figure 2. 


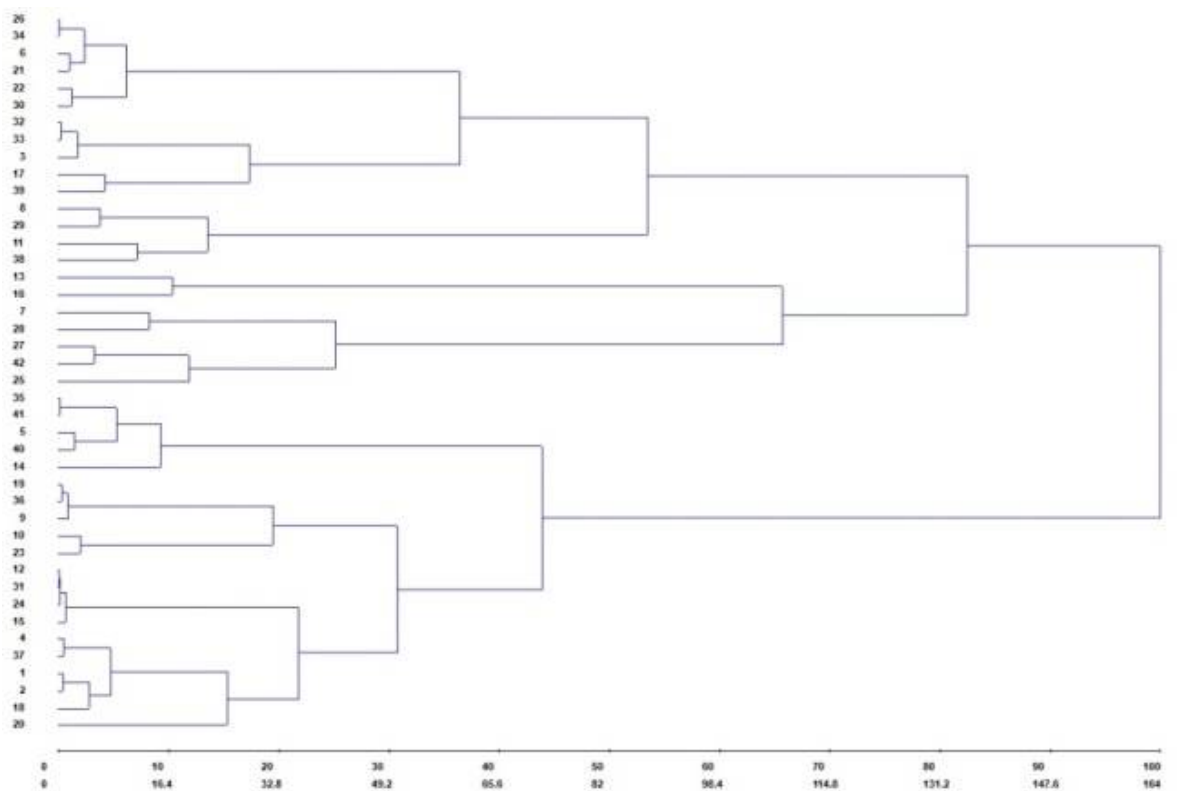

Figure 2. Dendrogram obtained based on the Generalized Mahalanobis Distance calculated in terms of four characters (leaf length, leaf width, number of lobes, and petiole length) among adult fig leaf accessions using Ward's method.

The dendrogram obtained by grouping the accessions shows that the individuals from the fig tree AGB studied could be divided into two large, well-defined hierarchical groups. However, the groupings formed within these had very different hierarchies, with the formation of subgroups with greater or less dissimilarities among themselves. In this sense, it was observed that, within each large group, there were large subgroups, containing small subgroups composed of very genetically similar individuals. For example, the first large group was formed by treatments 25 to 26 (Figure 2). Within this large group, four large subgroups, consisting of treatments 26 to 30,32 to 39,8 to 38 , and 13 to 25 , occurred, indicating a structured population for the characters analyzed. In this case, the treatments 8 , 29,11 , and 38 of the first subgroup were very similar to each other but formed a distinct subgroup when compared to the other genotypes.

In the second large group, consisting of treatments 16 to 26 , although there was a clear visual hierarchy the genotypes grouped more easily than in the first group. Three subgroups were formed, which contained accessions with phenotypes similar to each other. This demonstrates the distance between the large groups 1 and 2, with the latter being the least divergent among its accessions.

The number of lobes was the most promising leaf morphological character among those examined in this study due to its high heritability and high genetic correlation, corroborant to Caliskan and Polat (2012), which used the number of lobes per leaf as one of the essential parameters for the differentiation of fig genotypes in Turkey.

When analyzing variation in this character among accessions, the dendrogram showed low structuring among the accessions, indicating that this is a unique character for each accession. Thus, it was observed that the population studied had medium to high 
genetic variability, indicating that it is possible to identify the materials from different sources within it.

The use of cultivars adapted to different climatic conditions, soil, and production systems is a fundamental principle used to improve the productivity and quality of any fruit or vegetable (Mba et al., 2012). Therefore, the generation of new and more productive cultivars with superior qualitative characteristics, such as fruit color, flavor, odor, texture and color of the pulp, sugar content, acidity, and resistance to transport, among others, has been a significant challenge in the breeding of fruit plants.

According to Frankham (2005), genetic diversity is the key to a species' survival and adaptation to changes in the environment, and a fundamental task for scientists is to elucidate the mechanisms of the origin and maintenance of this variation (Platt et al., 2010; Huang et al., 2014). In addition, detailed information on genetic variability can be applied to reveal the demographic and structural history of the population of a species, and the genetic mechanisms behind its local adaptation and evolutionary changes (Hansen et al., 2012; Mita et al., 2013; Berg and Coop, 2014). The characterization of genetic diversity within germplasm banks is thus a key initial step in the successful growth and expansion of the culture of fig tree crops.

The main role of heritability is related to the fact that it expresses the reliability of the phenotypic value as an estimator of the genotypic value, such that the higher the heritability in selection (Acquaah, 2012). In the present study, the coefficient of heritability at the level of number of leaf lobes, determined through analyses of morphological differences of vegetative parts, the accuracy of genotype selection and the coefficient of genotype variation were significant, suggesting that this character may be promising to be a selection character for the identification of fig trees of different genotypes in Brazil, where propagation is done primarily by cloning.

It was possible to characterize fig tree accessions based on quantitative analyses of differences in the morphology of their leaves, to allow the selection of strains of this crop with desirable traits. Moreover, the most divergent accessions were found to be 'Genovesco', 'Brunswick', 'Troyano', 'Palestino', Accession 21, Accession 34, Accession 38, Accession 39, Accession 41, and Accession 42. These divergent accessions had characteristics of agronomic interest, which may thus be used in future studies on genetic improvement programs of the fig tree crops. Genetic analyzes at the DNA level, such as SSR molecular markers, will also be used to correlate the treatments belonging to the $\mathrm{BAG}$ in question

\section{ACKNOWLEDGMENTS}

The authors give thanks to the University of São Paulo State "Júlio de Mesquita Filho", Ilha Solteira and Dracena Campus, for the research assistantship postdoctoral development in Agronomy provided to the first author, and to Fundação de Amparo à Pesquisa do Estado de São Paulo (FAPESP), for financial assistance to the project.

\section{DATA ARCHIVING STATEMENT}

The data in this article were not submitted to any public database. 


\section{AUTHORS CONTRIBUTIONS}

Conceptualization: Rodrigues, M.G.F.; Boliani, A.C. Data acquisition: Santos, T.P.; Neves, V.A.B; Monteiro, L.N.H. Data analysis: Pavan, B.E.; Rodrigues, M.G.F. Design of Methodology: Rodrigues, M.G.F; Ferreira, A.F.A. W. Writing and editing: Rodrigues, M.G.F.; Monteiro, L.N.H.; Ferreira, A.F.A.

\section{REFERENCES}

Acquaah G (2012). Principles of plant genetics and breeding 2nd Edition: Wiley-Blackwell, 664p.

Barolo MI, Mostacero NR and López SN (2014). Ficus carica L. (Moraceae): An ancient source of food and health. Food Chem. 164: 119-127.

Berg JJ and Coop G (2014). A population genetic signal of polygenic adaptation. PloS Genet. 10: p.e1004412.

Brito JAR, Kaur R, Cetintas JD, Stanley ML, et al. (2008). Identification and isoenzyme characterization of Meloidogyne spp. infecting horticultural and agronomic crops, and weed plants in Florida. Nematology. 10: 757-766.

Caliskan O and Polat AA (2012). Morphological diversity among fi g (Ficus carica L.) accessions sampled from the Eastern Mediterranean Region of Turkey. Turk. J. Agric. For. 36:179-193.

Castellen MDaS, Ledo CADaS, Oliveira EJDe, Monteiro FLS, et al. (2007). Caracterização de acessos do Banco Ativo de Mamão por meio de análise multivariada. Magistra. 19: 299-303.

Cowart NM and Graham JH (1999). Within- and among-individual variation in fluctuating asymmetry of leaves in the fig (Ficus carica L.). Int. J. Plant Sci. 160: 116-121.

Cruz SM, Nery MC, Von Pinho EVR and Laia ML (2014). Molecular characterisation of radish cultivars. Rev. Cienc. Agron. 45: 815-822.

Cruz CD (2006). Programa Genes - Estatística Experimental e Matrizes. 1. ed. Viçosa: Editora UFV, 285p.

Domiciano GP, Alves AA, Laviola BG and Conceicao LDHCS (2015). Parâmetros genéticos e diversidade em progênies de Macaúba com base em características morfológicas e fisiológicas. Ciência Rural 45: 1599-1605.

Ferreira EA, Pasqual M and Tulmann N (2009). A. In vitro sensitivy of fig plantlets to gamma ray. Sci. Agric. 4: 540542.

Ferreira DF (2011). Sisvar: A computer statistical analysis system. Ciênc. e Agrotec. 35: 1039-1042.

Flaishman Ma, Rodov V and Stover E (2008). The fig: botany, horticulture, and breeding. Hortic. Rev. 34: 113-196.

Frankham R (2005). Genetics and extinction. Biol. Conserv. 126: 131-140.

Giraldo E, Viruel MA, López-Corrales M and Hormaza JI (2015). Characterization and cross-species transferability of microsatellites in the common fig (Ficus carica L.) J. Hort. Sci. Biotechnol. 80: 217-224.

Grum M and Atieno F (2007). Statistical analysis for plant genetic resources: clustering and indices in R made simple. Handbooks for Genebanks, n.9. Bioversity International, Rome, Italy.

Hansen MM, Olivieri I, Waller DM and Nielsen EE (2012). Monitoring adaptive genetic responses to environmental change. Mol. Ecol. 21: 1311-1329.

He SL, Hollingsworth P, Yi TS and Li DZ (2016). Environmental and historical determinants of patterns of genetic differentiation in wild soybean (Glycine soja Sieb. et Zucc). Sci. Rep. 6: 22795.

Huang P, Feldman M, Schroder S, Bahri Ba, et al. (2014). Population genetics of Setaria viridis, a new model system. Mol. Ecol. 23: 4912-4925.

Köeppen W (1948). Climatologia. México: Fondo de Cultura Econômica, 478p.

Mawa S, Husain K and Jantan I (2013). Ficus carica L. (Moraceae): Phytochemistry, traditional uses and biological activities Evid. Based Complement. Alternat. Med. 2013: 974256.

Matos G, Muñoz A and González J (2013). On the Generalization of the Mahalanobis Distance. In: Ruiz-Shulcloper J., Sanniti di Baja G. (eds) Progress in Pattern Recognition, Image Analysis, Computer Vision, and Applications. CIARP (2013). Lecture Notes in Computer Science, vol 8258. Springer, Berlin, Heidelberg.

Mba C, Guimaraes EP and Ghosh K (2012). Re-orienting crop improvement for the changing climatic conditions of the 21st century. Agriculture \& Food Security. 1: 7.

Mita S, Thuillet AC, Gay L, Ahmadi N, et al. (2013). Detecting selection along environmental gradients: analysis of eight methods and their effectiveness for outbreeding and selfing populations. Mol. Ecol. 22: 1383-1399.

Palace M, Sullivan FB, Ducey M and Herrick C (2016). Estimating tropical forest structure using a terrestrial Lidar. PLoS One. 11: e0154115.

Pèrez C, Canal JR and Torres MD (2003). Experimental diabetes treated with Ficus carica extract: Effect on oxidative stress parameters. Acta Diabetol. 40(1): 3-8.

Platt A, Horton M, Huang YS, Li Y, et al. (2010). The scale of population structure in Arabidopsis thaliana. PloS Genet. 6: e1000843. 
Raij BV, Cantarella H, Quaggio JA and Furlani AMC (1997). Recomendações de adubação e calagem para o estado de São Paulo. 2. ed. rev. atual. Campinas: Instituto Agronomico / FUNDAG, 285p. (IAC. Boletim Tecnico, 100).

Resende MDV (2007). Sistema estatístico e seleção genética computadorizada via modelos lineares mistos. Colombo: Embrapa Florestas, 359p. (in Portuguese).

Röper AC, Orabi J, Lütken H, Christensen B, et al. (2015). Phenotypic and genotypic analysis of newly obtained interspecific hybrids in the Campanula genus. PLoS One. 10: e0137537.

Rubnov S, Kashman Y, Rabinowitz R, Schlesinger M, et al. (2001). Suppressors of cancer cell proliferation from fig (Ficus carica) resin: Isolation and structure elucidation. J. Nat. Prod. 64: 993-996.

Stojanović M, Pezo L, Lačnjevac Č, Mihajlović M, et al. (2016). Biometric approach in selecting plants for phytoaccumulation of uranium. Int. J. Phytoremediation 18: 527-533 